\title{
シアトルの歴史地区におけるコミュニティ保全思想の提起とその背景 THE EMERGENCE OF THE NEIGHBORHOOD CONSERVATION IDEAS IN THE HISTORIC DISTRICT OF SEATTLE
}

\author{
阿 部 祐 子*
}

\section{Yuko ABE}

\begin{abstract}
The purpose of this study is to explore the preservation concepts of the Pike Place Market Historic District in Seattle, which was one of the earliest examples in the U.S. that included ideas of neighborhood conservation. To analyze the way to raise the concepts I studied the ideas and opinions expressed by the citizens' group advocating to preserve the district, especially by Victor Steinbrueck (1911-1985), an architect and the leader of the group.

The study shows that the preservation concepts based on Steinbrueck's socialism and regionalism were emphasized more clearly through a criticism on gentrification after the late 1960s. At that time Pioneer Square District, another historic district in the downtown, had succeeded in revitalizing by adaptive reuse of historic buildings, but at the same time low-income residents were forced out by steadily rising land prices and rents. Concerning that the communities around the Market would be lost for the same reason, Steinbrueck and other activists insisted to maintain communities and their activities as well as to preserve the market buildings. Thus the neighborhood conservation ideas were raised from a criticism against not only the urban renewal plan but also the historic preservation project that aim primarily to vitalize real estate market, and after the 1970s, such ideas were adopted in historic preservation policies of Seattle and other American cities.
\end{abstract}

Keywords : Historic Preservation, Neighborhood conservation, Victor Steinbrueck, Seattle 歴史保全，近隣地区保全，ヴィクター・スタインブルック，シアトル

\section{1.はじめに}

シアトル市では、1963 年にダウンタウン再開発計画が策定された 直後から、中心商業地区に隣接する 2 つ歴史的地区において保全 運動が展開された。1970 年に歴史地区として登録されたパイオニ ア・スクェア地区 1) と 1971 年登録のパイク・プレイス・マーケッ 卜地区 2)（以下「マーケット地区」と記す）である。この運動後、 シアトル市は歴史保全を都市政策として積極的に展開し、その分野 での先進都市と認識されるようなった ${ }^{3)}$ 。特に後者のマーケット地 区では、建造物等の物的環境のみではなく、地区内の商活動や低所 得者住宅の維持を規定しており、コミュニティの社会的特性も包括 した保全のあり方を提起した例としても評価されている ${ }^{4) 。 こ の よ ~}$ うな近隣地区保全 (=Neighborhood Conservation)の考え方は 1970 年代中期以降米国の歴史地区における重要課題であり5)、同国の歴 史保全の特徴を把握するための一助として、本論は 1964 年から 1971 年までのシアトルの保全運動における論点の分析を中心とし て、この思想が提起された経緯と背景を検証するものである ${ }^{6)}$

\section{2. 研究の概要}

シアトルの 2 歴史地区に関連する文献のうち代表的なものとして、 マーケット地区の通史である Shorett \&Morgan（1982＆ 2007）7)、 1960 年代の保全運動の記録である Brewster（1981）8）があるが、
これらは事実関係の記録であり、歴史保全の観点からの分析では ない。近年の研究としては、2 歴史地区の保全運動とダウンタウ ン都市政策転換の関連を政治的・社会的に分析した Lee（2001） 9)がある。これは、歴史地区設立の経緯を政治・行政の観点から分 析し、保全運動の都市政策上の位置づけを論じているが 10)、歴史 保全のあり方に関する議論には触れていない 11)

そこで本論では、マーケット地区保全運動のリーダーであり、 パイオニア・スクエア地区の史跡指定にも深く関与した、建築家 ヴィクター・スタインブルック (=Victor Steinbrueck, 1911-85) の思想を基に、保全理念の形成過程を分析するものである。研究

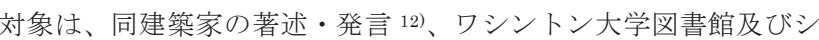
アトル市公文書館が所蔵する保全運動関連資料等 13)から、保全の あり方に関する議論の推移を検証する。以下、3.では保全運動の 基礎となったスタインブルックの建築観・歴史保全観、4 . では保 全運動における論点の変遷の過程、5.では運動を通して近隣地区 保全が提起された背景についてそれぞれ分析し、6.に理念形成の 経緯をまとめ同国の歴史保全における位置づけを考察する。

\section{3．建築の評価及び保全に関する基本姿勢}

シアトルでは 1953 年に初の建築史解説書 14)が発刊され、地域 建築に対する関心が高まっていった ${ }^{15) 。 さ ら に ~} 1950$ 年代後半に

\footnotetext{
$*$ 東京大学産学連携本部 特任専門員 $\cdot$ 工博
}

Program Officer, Division of University Corporate Relations, University of Tokyo, Dr. Eng. 
は、行政による高速道路建設や都市再開発計画に対抗して、建築家 達による自然環境・居住環境保全運動が拡大し、地域の環境特性の 保全が論争の対象となった。その中で、解説書の著者でもあるスタ インブルックは、都市・建築評論を通して建造物保存に関して積極 的に発言し、シアトルに相応しい歴史保全の推進を主張した。マー ケット地区の保全運動が始まる以前の作品、著作、発言からはその 基本となる考え方が把握でき、それが後年の保全理念の提起につな がっていったと考えられる。

これらの分析を通して、他の地域建築家と比べ特徵的な思想とし てまず指摘できるのは、建造物の「人間的価值（=human value）」 の尊重、及びそれを基準とした建造物保存を提案したことである。 「人間的価值」とは、コミュニティへの貢献や市民の生活環境との関 連など、建築の機能的・社会的・環境的側面の評価である。

それを重視する姿勢は彼の設計作品にみられる。例えば、1940 年代から 50 年代には労働者向けの住宅など小規模・廉価な建築を 多く設計し、そこには一般労働者の生活向上という社会主義的志向 がみられる ${ }^{16)}$ 。建築評論においても、1959 年から約 3 年間続けら れた地方紙のコラム 17)で、特に開拓期の労働者住居の機能的価值に 言及するなど、建築物を形態のみでなく、そこに存在する居住者の 生活形態やコミュニティとの関連から一体的に評価する視点が見ら れる。そして、1962 年の著書でこれについて「人間的価值」という 言葉で定義している ${ }^{18)}$ 。

このような建築と市民生活との関連性を重視する視点は、建造物

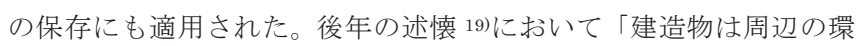
境やそれが存在する近隣地区のために設計されるべきである。個別 のものとして設計するのではない。(中略) 近隣地区から建造物を取 り除く前にも同様の検討が必要である」と述べており、建造物の環 境やコミュニティにおける存在意義を保存への判断基準とすべきと いう考え方を示している。このような「人間的価值」重視の姿勢は 晚年まで変わらず20)、保全運動を通してより強固なものとなった。

もう 1 つの特徵として、建造物は他都市で設定された価值基準で はなくシアトル市民にとっての価值に基づいて評価・保全されるべ きであると主張していることが挙げられる。後に「『古さ (=antiquity)』は相対的なもの」という表現を用いて主張したように 21)、西 海岸の都市の歴史は短くても、地域住民にとって価値ある歴史資源 の存在を訴えている。そして、歴史的建造物の価值は他都市での基 準に従うのではなく、独自の価值観に基づいて評価すべきであるこ とを主張している。

例えば、開拓時代の消防署や簡易宿泊所の保全運動 22)、あるいは 庶民に安価な食品を提供する公設市場であるパイク・プレイス・マ 一ケットへの高い評価など、都市固有の歴史を表す建造物を重視す る中に彼の価值観を見ることができる。また、パイオニア・スクエ ア地区についても、「(国内他都市と) 比較すれば優れた建築ではな い」ことを認めながら、都市発祥の地として開拓時の歴史を示すも のとしての重要性を主張している 23)。このような地域主義的な視点 に基づき、従来の政治史や建国史の象徴のみではなく、庶民の生活 史に深く関わった建造物・構造物へと保全対象が拡大した。

建築の社会的意義や都市の独自性を尊重した彼の論説は、地域の 既存住民のみでなく、第二次世界大戦後に移住してきた新規住民の 賛同も得るようになり、1960 年代後半に展開された保全論争を通し
て、シアトルの歴史保全の特徴を形成する基本的思想となった。

\section{4.マーケット地区の保全理念の形成過程}

1964 年 11 月から約 7 年に亘るマーケット地区の保全運動を通 して、スタインブルック率いる保全運動団体フレンズ・オブ・マ ーケット（以下「FOM」と記す）は「何が重要か」「何を保全す べきか」という議論を行政機関や経済団体等と戦わせており、そ れがこの地区の保全理念に大きな影響を与えた。本章では、保全 運動に関する記録記事、及び保全団体による書簡・声明文・記者 発表、及び関連するスタインブルックの著述・発言等を基に、論 点がどのように推移し保全理念として提起されたか、その形成過 程を検証する。

保全運動の記録資料の分析から、パイク・プレイス・マーケッ 卜地区保全運動は大きく3つの段階に分けられることがわかる ${ }^{24) 。 ~}$ (1)1964 年 1967 年 : マーケット存続にむけて、市民の関心喚 起・保全への賛同者獲得活動の展開。

(2) 1968 年 1969 年 : 行政による中核建造物のみの再生・再利 用案提示を機に、「保全か取り壊しか」の議論から「何をどの ように保全すべきか」という論争に発展。

(3)1970 年～1971 年 : 歴史地区指定に向けての政治的・司法的 闘争の展開。

この中で FOM の発信は、(1)の期間には市民に向けての公設市場 と地区の魅力を人々の訴えるものが多く25)、(2)の期間には行政案 に対抗するための地区特性の解䣋と保全のあり方に関する主張が 多い 26)。一方、(3)期間は法的手続に関する政治的議論であり、 保存理念に係る部分は少ない27)。そのため、ここでは(1)、(2)の期 間を中心に、地区特性の評価とそれを反映した保全理念に関して 論じる。

保全運動以前のものとして、シアトル・シティスケープ（1962 年発刊）における解説 28)では、「特にユニークで、華やかで全て の感性を刺激する場」と評し、「我が国で最も楽しくピクチャレス クなショッピング街の 1 つとして、それを構成する多様な人々、 商店、商品などを紹介しており、この時点では、これらを視覚的 要素として客観的に観察しているのがわかる。

さらに運動初期には、1965 年の新聞連載コラム 29 などにおい て、庶民に廉価な食品を提供するために創設され、誰にも開かれ た販売システムを維持してきたことなど、シアトルの生活史にお ける重要性を述べている。同様に、1967 年の雑誌記事 30)には、 地区保全の意義として「廉価な商品の提供」という機能をあげ、 保全運動の進行と共に、生活支援という機能的側面に関する評価 が見られる。

1968 年 3 月に市が発表した地区再開発計画案は、市場の中核 建造物数棟を保存し、内部をショッピング・センターとして再利 用するという案 31 )であった。これに対し FOM は、批判と代替案 作成への要求を求めた声明 32 )を発信しており、この内容は運動の 論点が「市場の保存」から「何をどのように残すべきか」という 保全のあり方に変化したことを示している。この声明の中で、「マ 一ケットは我々が守りたいと考えているものの覆いに過ぎない」 という主張が示され、低所得層対象の食品市場としての機能とそ れを構成する商店や販売システム等の維持を訴えている。さらに、 
市場の中核建造物の保存のみでなく、機能的・社会的に市場との関 連が深い周辺地区を包括した保全を求めており、保全対象の拡大が 見られる ${ }^{33)}$

1968 年に発刊された著書『マーケット・スケッチブック』34)では、 地区の視覚的・景観的特徴とともに、そこで働く人々やその商品、 及び来訪者の活動が解説されている。市場として保全す心゙きものと して建築・空間・人間を等価の要素として扱っており ${ }^{35}$ 、特に人々 の活動について、前著「シアトル・シティスケープ」よりも詳細か つ深い分析がなされている。さらに、マーケットとそれを取り巻く 周辺エリアとの関連についても分析し、市民の日常的な買い物や娛 楽の場として両者が不可分であることを強調している ${ }^{36)}$ 。同年の地 方紙の取材には 37)、「重要なのはマーケットにおける社会的融合と 人々の空間体験である」と述べ、空間的特質と人々の活動の総体的 な評価と保全の必要性を強調している。

1969 年以降になると、建築・空間よりも人間活動に重心が移り、 地区の商店・住宅の維持を最優先と寸る主張が鮮明になっていった。 例えば、1969 年 2 月の専門誌への投稿記事 38 )では、喪失が懸念さ れる市場周辺の商店・事業者、地区住民の保護、及び低価格の食品 を消費者に提供する商システムの維持に関する主張が中心となって いる。同年 3 月の新聞記事 39 には「マーケットを守ることはただ建 造物を守ることではなく『我々の関心は人間の活動だ』」と述べ、同 様に 4 月の FOM の投稿記事 40)には「歴史保全は単に『年期の入っ た外見』を云々するものではなく、人々の活動や文化に関わるもの である」と記すなど、論争の焦点は建造物から地区の商店・利用者・ 居住者とその活動へと完全に移行していることがわかる。

また、同月の取材記事 ${ }^{41) て ゙ は 、 「 ハ ゚ イ ク ・ フ ゚ レ イ ス ・ マ ー ケ ッ ト ~}$ 地区の 600 人近い住民は『多かれ少なかれエリアに満足しており、 選んでそこに住んでいる。(中略）再生計画は適切な住宅を供給し、 そして現計画案のような破壊的な変化を与えないものである(べき だ)』」と述べ、同 6 月の雑誌記事 ${ }^{42)}$ では市の計画案における周辺住 民・小規模商店排除の可能性を強く批判している。これらは人々の 活動の中でも特に市場周辺住民とその生活環境の保護が主眼となっ たことを示している。

このように、保全対象に関する議論は、初期には建造物と空間で 構成される視覚的要素、人々の交流の場としての魅力など、都市空 間としての価値評価から始まり、徐々に廉価な食品の提供、あるい は小規模事業者の育成等の都市機能としての評価へと拡大した。さ らに、所得・階層を超えた融合や低所得者居住区としての社会的意 義の評価へと移行し、論争の焦点も建造物群から市場の商形態、そ して既存コミュニティの維持へと変遷した。

1970 年に FOM は、市場の中心建造物群のみでなく、市場機能と 強い関連を持つ周辺地区の商店と住宅群を包括した保全区域の指定 を求め、最小限の指定に留めようとする行政 43 ) との法的闘争を展開 した。結果として、1971 年 11 月に市民投票 ${ }^{44)}$ よってその要求は 達成された。

スタインブルックと FOM の主張は、歴史地区条例に反映され、 物理的環境の保存基準となる『デザイン』と、空間用途・販売形態・ 商品内容等を規定する『用途 (=use)』の 2 部からなるガイドライ ン策定 ${ }^{45}$ ) とつながった。後者では、農家による直接販売という商 形態の維持や低所得者対象の商店・住宅の確保などを規定しており、
地区の社会的・経済的特質の総体的保全・強化を図っている。

\section{5. 地区高級化（=gentrification）批判と近隣地区保全の提起}

前章に述べたように、1968 年に市の最終計画案が発表されて以 後、スタインブルック率いる FOM は地区の活動やコミュニティ 特性など、社会的・経済的側面を包括した保全理念を掲げるよう になった。このような保全の論点が拡大した背景として、当時の ダウンタウンの社会状況があると考えられる。

前述の通り、スタインブルックは建築の持つ市民生活やコミュ ニティに果たす機能的・社会的意義を重んじ、都市内の労働者や 社会的弱者の生活環境に対して強い関心を持っていた。特に、2 つの歴史地区とそれらを結ぶファースト通り沿道は、開拓時代か ら続く低所得層向けの商店や住宅が集積するエリアであり、この 地区の保全については、都市更新事業（=urban renewal）計画が 具体化した 1960 年代初頭から多くの発信を行っている。例えば、 1966 年 5 月の新聞記事 46 )では労働者居住区を大きく改変する計 画を批判し、歴史的建造物の保全などを通した住居や小規模商店 の維持と生活環境向上が「真の都市更新」であると述べている。

このような 1960 年代中期までの発信は、大規模再開発に対す る批判であり、「破壊」に対する「保全」への主張であるが、1960 年代後期になり、パイオニア・スクエア地区での歴史的建造物群 の再生・再利用が進むとともに、その批判の対象は変化していく。

パイオニア・スクエア地区では、1963 年の計画によって都市更 新事業による再開発が計画されていたが、一方で 1964 年から建 築家やデベロッパー等のグループが自主的に建造物を買い取り修 復して、新たなテナントを誘致するという活動を進めていた ${ }^{47) 。}$ 市長と市議会が再開発事業の主導権を巡って対立し計画実施が遅 れる中 ${ }^{48)}$ 、建築家グループによる修復事業は進み、歴史的建造物 の再生が地区の経済活性化にも有効であることを証明した。それ を受け、地権者等の賛同もあり、1967 年には市も歴史地区設立へ の検討を開始した ${ }^{49)}$ 。

同地区では建造物群の外観を修復・復元し、内部を改修して新 たな機能に供する手法、アダプティブ・リユース (=adaptive reuse) を広範囲に適用した例として、全米的にも高く評価されている50) 19 世紀末の石造建造物は建築家・弁護士等の事務所、店舗、中高 級アパートに再利用され、それによって不動産価值は急速に高ま り、地区再生は成功したように見えた。

しかし一方で、この地区に居住していた低所得層やそれを対象 とした商店は、改修に伴う移転要請や賃料の高騰のために地区か らの転出を余儀なくされた。1960 年から 1968 年に間に同地区の 既存人口の多くが流出し 51)、保全活動が開始される以前と歴史地 区設立の検討が始められた時点とでは住民・事業者が大きく入れ 替わった。つまり、低所得層の住民にとっては、歴史的建造物群 の再生によっても生活を圧迫されるという状況が生まれた。

都市更新事業のみでなく歴史保全活動によっても低所得居住者 の排除が起こる可能性があるということは、スタインブルックを はじめ保全運動家の問題意識を高めた。1967年7月のパイオニ ア・スクエア地区の都市更新計画に関する地方紙の取材52)に対し て、「人々の（のための）改善が最初であり、建造物の再生はそれ からだ」と述心゙、既存居住者の住環境改善の優先を訴えている。 
そして、1968年以降、ファースト通り、マーケット地区等ダウンタ ウンの労働者居住区の高級化を問題視する著述・発言が多くみられ 53)、彼の懸念の大きさを示しているといえる。

さらに、スタインブルックの運動を補佐した建築家オーリンは、 1969 年にダウンタウン内の低所得居住者の現況調查 54 )を行ってお り、同地区での建造物再生・再利用が居住者圧迫につながっている ことをデータに基づいて批判している55)。スタインブルックもこの 調査に協力しており、強い問題意識を抱いていたと考えられ、それ により彼の運動の重心が居住者保護に移行したことが後年の述懐か らわかる。

例えば、1978年10月のインタビューでは、パイオニア・スクエア 地区における建造物の再生活動が革新的であったことを評価しな がらも以下のように批判している。

「(建造物の再生・活用が低所得層の住民の排除につながっ たことについて）私は常に建造物保全の持つそういった側面に ついて憂慮している。他の面ではパイオニア・スクェア地区に ついて喜ばしく思っているが、社会的側面についてはとても不 本位だ。」56)

さらに、1980 年 5 月のインタビューでは自身の運動への評価と して、コミュニティの活動の維持が依然として課題であるとことを 述べている。

「多くの歴史的建造物が残され、パイオニア・スクエアが文 化的性格を得たことに感謝している。しかし、私はただ建造物 のみを維持したいのではなく、今存在し人々に利用されている 場の維持が望まれる。」57)

また、1984 年の書簡には、これまでの保全運動を総括し、その目 的が人々の保護であると明示している。

「パイオニア・スクエアでは、早期から歴史的建造物の保全 を強く支持しながらも、私は常にスキッド・ロードの人々への 福祉のために戦っている。」「我々のスローガンであった『マー ケットを救おう』は、明らかに市場の都市における社会的・経 済的・美的価值の維持を意味する。これは特に小規模事業者と 低所得居住者の保護を含むものである。」58)

他都市において歴史的建造物のアダプティブ・リユースが都市中 心部の再生に有効であるという認識が広がり始めた 1960 年代後半 59)に、パイオニア・スクエア地区の状況を通して、シアトルの保全 活動家は、それもまた地区高級化と都市内居住者の圧迫につながる ことを問題視し始めた。特にパイオニア・スクエア地区と同じく低 所得層の居住地区であるマーケット地区では、より安定したコミュ ニティが形成されており 60 、その保全は居住の場としてのダウンタ ウンの社会的・文化的特質を継承していくためにも重要と考えられ た ${ }^{61)}$ 。そのような地区高級化の進行とそれに対する批判を背景に、 1960 年代末の同地区の保全論争は一層社会的・福祉的性格の強いも のになったと考察される。

\section{6. まとめ}

本論は、スタインブルックの著述・発言を中心として、コミュニ ティの社会的保全の考え方が形成された過程と背景を考察した。そ こから明らかになったことを整理する。

シアトルの歴史地区において早期にコミュニティの社会的・経済
的特性の保全という理念が導入された社会的背景として、先行し たパイオニア・スクエア歴史地区における地区高級化と既存住民 の追い出しという状況があった。同時期にマーケット地区でも歴 史的建造物のアダプティブ・リユースによる地区再開発計画が策 定され、コミュニティの消失が拡大することを懸念した保全運動 団体は、建造物という物的環境の保存よりも地区の経済活動や社 会的構成といったコミュニティ特性の維持に重きを置いた議論を 展開寸るようになった。このように、同地区の保全理念はスタイ ンブルックの社会主義的・地域主義的思想を基盤とし、地区高級 化進行への批判を契機として明確化されたと言える。

既往研究 ${ }^{62)}$ ではパイオニア・スクエア地区とマーケット地区の歴史 保全を同一視点で評価する傾向にあるが、当初経済活性化を主眼と していた前者とは異なり、後者には明らかに地区高級化防止に対する 意思がみられ、短期間にそれぞれ異なる保全のあり方を提起したもの であった。そしてその後になり、相互に補完しながら ${ }^{63)}$ 同市の歴史地 区保全事業を充実していったと言える。

最後に米国の歴史保全史の中での位置づけを考えてみたい。同 国の歴史保全は 19 世紀後半から中流婦人の社会奉仕活動を核と して、愛国心・郷土愛の高揚という教育目的から発展した。その ため、政治史・建国史に関わる歴史的建造物の選定・保存・展示 が中心であったが、1960 年代になり中心市街地再生策としての効 果が注目されるようになった。1966 年連邦政府の法的措置も伴い、 歴史地区指定と建造物再生・再利用が全米の都市で展開された ${ }^{64)}$ しかし、1970 年代中期以降、そのようなアダプティブ・リユース による不動産価值高騰によって起こる既存住民排斥、コミュニテ イの変質に対する問題意識が高まり、低所得層・少数民族居住区 の維持という社会福祉的な施策が多くの歴史地区で検討されるよ うになった ${ }^{65)}$ 。

そのような動きの中で、1960 年代後半にシアトルのダウンタウンでは、 2 歴史地区の保全運動が同時並行で進んだことにより、その後全米各 地の歴史地区において指摘される課題に短期間に直面することにな った。それに対して、保全活動を進める建築家の地域特性・住民生活 重視の思想を反映し、近隣地区保全を包括した特徵的な歴史保全の あり方を提起したと言える。

一方、 1980 年代以降、このような歴史保全の拡大と多様化によ る問題点も指摘されている。歴史保全は一般市民の社会活動の範 囲を超え、住宅供給、福祉、住民参加等に関するより広範で高い 専門性を必要とするようになり、人材不足が課題となった ${ }^{66) 。 さ ~}$ らに、住民意思の尊重は、生活に密着した歴史保全を実現する反 面、建造物の歴史的価值や復元の正確性等学術的な判断との乘離 が生じる場合も多く、過度に過去を美化した復元や時代的混乱な ど、歴史的正確性の点での課題も指摘された ${ }^{66)}$ 。

マーケット地区においても、コミュニティや商活動といった無 形資源の時間的 - 質的変化への対応、地区内の社会的 - 経済的二 ーズと歴史的正確性保持のバランスといった課題 ${ }^{68)}$ について恒 常的な論争が現在に至るまで繰り広げられており、近隣地区保全 の解勫や実務上の難しさを物語っている。

このように、1970 年代初頭にシアトルの歴史地区で提起された 保全理念は、歴史保全におけるコミュニティ特性保全という課題 への視座を開くものであったとともに、米国の歴史地区保全の質 
注

1）現在の中心商業地区の南端に接する同地区は、1851 年の入植以降開拓期 の中心商業地区、及び労働居住区として発展した。1900 年以降の中心商業 地区の北部への移行、大恐慌を経て地区経済は著しく衰退し、低所得居住 者のみが残る状況となった。

2）現在の中心商業地区の北西に接する、1907 年に開設された公設市場とそ の周辺地区である。農家と消費者とが直接取引する市場で、第二次世界大 戦前はその規模、整った運営システムで国内でも注目された。しかし、第 二次世界大戦中の日系農家の強制收容、戦後の保存・輸送技術の発展等に よって市場の出店数、来場者数は大きく減少した。

3) Carlton, Knight: Seattle: a City Where Preservation Is a Priority, Preservation News, p.8, 1973.11; Delahanty, R. \& A. McKinney: Preserving the West, pp.157-164, 1985 等。また Chao, Julie: Seattle's Landmarks Aren't All That Old, But City Isn't Either: It's Crazy about Preservation, The Wall Street Journal, 1995.9.19 は批判記事であるが、他都市に比較し て歴史保全体制が充実していることを示している。

4) Peirce, Neal R: Preservation that Values Buildings - and People, The Washington Post, 1978.5.6; 同: Seattle Does It Right, Seattle Post -Intelligencer, 1978.5.11; Ford, Larry R: Urban Preservation and the Geography of the City in the USA, Progress in Human Geography, vol. 3 no.2, pp.211-238, 1979; Birch, E. \& D. Roby: The Planner and the Preservationist, American Planning Association Journal, vol.50, pp. 197-204, 1984; Tyler, Norman: Historic Preservation: an Introduction to Its History, Principals, and Practice, W.W. Norton, pp. 22-23, 2000 等

5)米国の歴史地区保全を歴史的に論じた上記 Ford (1979) 及び Birch \& Roby (1984); 英国との比較の中でその特徴を論じた Barthel, Diane: Historic Preservation: Collective Memory and Historic Identity, Rutgers University Press, pp.2-10, 13-34, 1996; シアトルの歷史保全史においてコミ ユニティ計画との一体性を示した Kreisman, Lawrence: Made to Last, Historic Seattle Preservation Foundation, pp.22-23, 1999 等

6）本論は、拙著：シアトル市の 2 歴史地区における保全運動とその論点，日 本建築学会大会学術講演梗概集 F-2, pp.351-352, 2007、及び学位請求論文 『歴史地区におけるコミュニティ保全思想の背景と意義』,2008 を基に抜 粋・加筆したものである。

7) Shorett, A. and M. Morgan: Pike Place Market: People, Politics, and Produce, Pacific Search Press, 1982; 同: Soul of the City: The Pike Place Public Market, The Market Foudation, 2007

8) Brewster, Joyce S.: Market Wars", The Weekly, 1981.9.23

9) Lee, Sohyun P.: From Redevelopment to Preservation: Downtown Planning in Post-War Seattle (doctoral thesis in University of Washington), 2001

10)Lee (2001)は、当時の行政記録等を基に、「市民の勝利」と言われる 2 歷 史地区の保全運動の意義を検証している。運動は住民意思の反映というょ りは旧来の経済エリートと新興の文化エリートとの権力闘争ではあったが、 同時に地区特性を尊重した都市政策への転換点となったことを論じている。

11)Lee (2001)の論文は政策転換に関する分析であり、保全運動団体と行政の 保全論争にはほとんど触れていない。他に Morley, Judy M.: Historic Preservation and the Imagined West, University Press of Kansas, pp. 67-126, 2006 は 2 歴史地区の建造物保存上の問題点を指摘しているが、2 地区の課題を一体的に論じており、各地区の特徴分析として十分ではない。

12) スタインブルックの自著（著書 6 、論文 7 、新聞記事 149 )、取材記事等に おける発言（マーケット関連論文 17、新聞インタビュー記事 105)、及び ワシントン大学特別資料室に収蔵された自筆原稿 20 点（文書ファイル \#1985,\#3252,\#3252-6 より抽出)を検討対象とした。

13)保全運動団体フレンズ・オブ・マーケットの記録文書から、声明 25 点、 記者発表 39 点、発信書簡 26 点を抽出し検討対象とした。

14)Steinbrueck, Victor: Seattle Architecture, Reinhold Publishing, 1953 15)上記の本はアメリカ建築家協会の全国大会がシアトルで開催されること
を期にまとめられたもので、その他 Architectural Record 誌 1953 年 4 月号の記事 Architecture of the Northwest”(pp.133-178)等の発信を通 して、地域の独自建築への注目が集まった（Ochsner, Jeffrey K.

Shaping Seattle Architecture, p.xxxiii, 1994 参照)。

16)作品解説として 700Sq. Ft. House, House \& Home, pp.112-115, 1952.8; Compact House with a Sense of Spaciousness, Architectural Record, pp.159-163, 1953.4 等; 建築観を示寸論説として Have We an Indigenous Northwest Architecture?, Architectural Record, p.145, 1953.4; Vieth, Thomas: Victor Steinbrueck, Shaping Seattle Architecture (Ochsner, Jeffrey K. ed.), pp.276-281, 1994 等。

17)地方紙 The Argus に 1959.10-1962.8 に連載された、地域の建築・景観 に関するエッセー。同記事内の開拓期の労働者住宅解説に見られる社会 主義的視点に関しては、Ochsner, Jeffrey K.: Victor Steinbrueck Finds His Voice: from the Argus to Seattle Cityscape, Pacific Northwest Quarterly, vol.99 no.3, pp. 122-133, 2008 が論じている。

18)Steinbrueck, Victor: Seattle Cityscape, p.28, 1962

19)Collin, Alf: Victor Steinbrueck- a Look Back at Him as a Teacher, The Seattle Times, 1976.7.18

20)死（1985.2.15）の前年に書かれた書簡には彼の活動の主眼が「人間的 価値」であることが特に强調されている（同書簡は、追悼記事 Human Value were First Concern of Architect Victor Steinbrueck, Seattle Post-Intelligencer, 1985.2 .18 に掲載)。

21)Steinbrueck, Victor: Historic Preservation Viewed with Alarm, Innovations in Wood, vol.III no.2, 1967 (ワシントン大学特別資料室収 蔵ファイル\#3252-6 Box3 Folder3 内の校正原稿、出版年は推定）では、 「歴史保全では、『古さ』は相対的なものである。西海岸の歴史は 1 世紀 余にすぎず、多くの地域ではそれよりさらに短い。地域の歴史を示す建 造物やエリアはまだ残っており、それらは我々の歴史と人間的価值を思 い出させる意味を持つだろう。」と述べている。他にも Everyday Architecture in the Puget Sound Area, Space, Style, and Structure (Vaughan, Thomas. ed.), p.652-655, 1974; Concern about Historic Preservation in Seattle, 1976(ワシントン大学特別資料室收蔵 ファイ ル\#3252-6 Box4 Folder4 内の手書き原稿）等において同様の言葉を用い ている。

22)McDonald, Lucile: Preservation of 4 Old Buildings Urged, The Seattle Times, 1960.10.2; Schear, Rill: Architect has Kind Words for Fire-Station Designers, The Seattle Times, 1963.4.7

23)Hutchison, Susan: Advice on Pioneer Square Renovation, Seattle Post-Intelligencer, 1969.2.28

24)ワシントン大学特別資料室収蔵文書ファイル\# 1985、及びシアトル市公 文書館收蔵 “Pike Place Market” ファイル内の FOM の発信文書、書簡 等の発信年月・発信先・主題の整理に基づく。

25) 上記資料内の FOM 発信文書では、この期間はイベントの案内や出版活 動など、市民への普及啓発を中心に活動していることがわかる。結果と して、約 5 万人の署名を集め市の取り壊し計画を覆した。

26) 1968 年 3 月以降の同上資料等では、市の計画への批判と保全対象拡大 への主張が中心となっている。また、Shorett＆Morgan (1982)、Brewster (1981) は、同月の市の最終計画案への対応について FOM 内でも意 見の対立があり、組織的にも大きな転換があったことを示している。

27)1970 年初以降の FOM 関連文書は、歴史地区登録に関寸る法的手続や 係争などに関する市・州・連邦政府向けの発信文書が中心となっている。 また、1971 年 5 月以降は市民投票にむけての選挙運動に移行している。 28)Steinbrueck, Victor: Seattle Cityscape, University of Washington Press, p.114, 1962

29)Steinbrueck, Victor: The Market Place, Seattle Post-Intelligencer, 1965.12 .26

30)Steinbrueck (1967）（注 21, Innovations in Wood の記事) 31)City of Seattle: Pike Plaza Redevelopment Project, 1968 32)FOM $の$ 声明 Statement for Friends of Market Regarding Redevelopment Proposals, 1968.3.18、及びその基となったスタインブルックの書 
簡 Statement Regarding Alternate Design Proposals for Pike Plaza Redevelopment Project, 1968.3.13 (ワシントン大学特別資料室収蔵ファイ ル\#1985, Box2 Folder16)

33)上記声明文において、現在の農産市場として機能の重要性を主張するとと もに、「文脈から切り離せば、目的を持って複合的に活動する生命体（= organism）ではなく、過去のモニュメントになってしまう」と述べ、中核 建造物と周辺地区との関連性と一体的保全の必要性を主張した。

34)Steinbueck, Victor: Market Sketchbook, University of Washington Press, 1968

35)上記著書発刊時のスピーチ原稿と推定される Steinbrueck, Victor: Market Sketchbook Brief（ワシントン大学特別資料室収蔵ファイル\#1985 Box3 Folder5 の手書き原稿) においてマーケットの存在意義として 7 項目 に整理しており、この視点をより明確に示している。

36)Steinbrueck (1968) 本文 9 頁目の解説文等。

37)Colorful Pike Place Market May Get Scheduled Facelift, UW Daily, 1968.11.7

38)Steinbrueck, Victor: Pike Place Market vs. Urban Renewal, Preservation News, 1969.2

39)Hutchison, Susan: Pike Place Hurricane, Seattle Post-Intelligencer, 1969.3.13

40)Tanner, Elisabeth: Friends of the Market- Urban Renewal for Pike Place Wrong, The Seattle Times, 1969.4.3

41)Jones, Marjorie: Skid Road Renewal Seen as Aid to Business, not Residents, The Seattle Times, 1969.4.9

42)Steinbrueck, Victor: A Man, a Market, \& Mankind, Queen City, vol.1 No.6, 1969.6

43)スタインブルックは市場の周辺地区も含めた 17 エーカーを史跡登録する よう州政府に申請書を提出し、1970 年 2 月に一旦承認された。それに対し て、シアトル市議会は市場中心建造物数棟を対象とした 1.7 エカーへの 縮小を決定し、州政府一変更を申請し承認された。FOM はこの手続きの不 当性を訴え、州・連邦政府等への請願活動、及び法廷闘争を展開した。

44) シアトル市の市民発議制度 (=Initiative) に従い、1971 年 11 月 2 日市議 会選挙と同時に 7 エーカーの歴史地区設立への是非を問う投票が実施され、 設立が決定した。

45)Pike Place Market Historical District Ordinance (No. 100475) 1971. 12.1、及び The Guidelines- Pike Place Market Historic District, 1974 46)Steinbrueck, Victor: Seattle Public Market - *to Be or Not to Be?, Seattle Post-Intelligencer, 1966.5.1

47)1963 年建築家アンダーセン（=Ralph Anderson）等が地区内の建造物を 買い取り、修復して不動産価值を高め、新たなテナントに貸すという活動 を始めた。この事業の成功によって、地区内の建造物所有者も参画するよ うになり、徐々に再生される建造物が増えていった。

48)Lee（2001）は行政文書を基に、市長と市議会の対立の状況、及び市議会 が対抗措置として歴史地区保全の検討を始めた経緯を詳細に述べている。

49)1967 年にモデルシティ事業地区に指定され、行政、住民・事業者等が参 画した検討会が設立され、そこで歴史地区登録への要望が出された。それ に伴い 1968 年にスタインブルックに地区の建造物調査が委託された。

50)Kreisman (1999) p.15 では、登録当時「米国内で最も早く大規模な歴史地 区の 1 つだった」と述べている。また、建造物群再生による地区活性化の 成功については、The National Trust for Historic Preservation: Economic Benefits of Preserving Old Buildings, 1976; Carlton (1973); Delahanty \& McKinney (1985)等に論じられている。

51)1969 年のダウンタウン内の低所得居住者の実態調査記録 Olin, Laurie: Breath on the Mirror-Seattle's Skid Road Community, 1972 はパイオニ ア・スクエア地区の居住者が 1960 年から 68 年の間に激減 (59\%減少 : p.13 注 1 , 原典は計画審議会資料) と述べている。また、Lee (2001) もpp.96-97 でセンサスデータから同様の状況分析を行っている。

52)Coffman, Larry: 'Human Renewal' is Key Part of Pioneer Square Project, The Seattle Times, 1967.7.25

53)例えば、Steinbrueck, Victor: What's All This Fuss about the Market?,
Seattle Post-Intelligencer, 1969.6.16; Jones, Marjorie: Skid Road Renewal Seen as Aid to Business, not Residents, The Seattle Times, 1969. 4.9 におけるインタビュー; FOM の声明文 1968.12.10; 同報道発 表資料 1969.3 .12 等。また、マーケット地区の保全はアダプティブ・リ ユースの先例であるギラデリ・スクエアとは異なるものであるべきとい


Wrong?, Queen City, vol.1 No.6, 1969.6; The Seattle Times の記事 Preciousness of Pike Market Stressed by Visiting Expert, 1969.4.19 等 に見られる。

54)注 51 参照。居住者の構成、生活形態、行動範囲等を地図、スケッチ等 を用いて現状と課題を示している。

55)Olin (1972) pp.44-45, 51

56)Collins, Alf: Victor Steinbrueck- The 'Necessary Gadfly', Seattle Post-Intelligencer, 1978.10.15

57)Honig, Doug: Planning for Lovers and Friends- Victor Steinbrueck on Livable Seattle, Seattle Sun, 1980.5.14 この後に、低所得居住者保 護が彼の都市保全運動の焦点となったことを述べている。

58)Seattle Post-Intelligencer, 1985.2.18（注 20 参照）。

59) 1960 年代中期以降、サンフランシスコのギラデリ・スクエア（1964 年 開業)、ボストンのファニュアルホール・マーケットプレイス（1966 年 史跡登録）等歴史的建造物の再生・機能転換による地区活性化成功が国 内一の普及につながった。

60)Olin (1972) p.22; Greenleigh Associations: A Study of the Residents of the Pike Plaza Redevelopment Project Area（シアトル市委託調查報 告書), 1968.4 等

61)シアトルを始め西海岸の都市では、港湾周辺の工業地区と隣接寸る労働 者居住区を核として都市が形成されたものが多い。これらの居住区は開 拓期からの続く比較的安定したコミュニティを維持し、都市の文化的特 徴を形成している場合も多く、そのため地区高級化による変質に対して 否定的な見方も強い。郊外化によってダウンタウンから中産階級が流出 し、その結果として都市内居住地区の荒廃・スラム化が進んだ東部・中 西部の都市とは異なる側面を持つと考えられる。

62)注 11 参照。

63)スタインブルックは、1960 年代前半のパイオニア・スクエア地区での 歴史的建造物保存活動の進展が後のマーケット地区の保全運動の後押し となったことを述懐している（Seattle Post-Intelligencer, 1978. 10.15）。 逆に、1960 年代末の保全運動を通したコミュニティ尊重への世論の高ま りを受け、1970 年代以降パイオニア・スクエア地区で低所得層保護の施 策が徐々に強化されていった（同地区での官民の施策が段階的に変化し ていった過程については、Morley（2006）p.89に解説されている)。

64)米国の歴史保全史については、西村幸夫 : 都市保全計画, 東京大学出版 会, pp.569-639, 2004; Murtagh, William J.: Keeping Time (Revised Edition), John Wiley \& Son, pp.25-77, 1997; Weinberg, Nathan: Preservation in American Towns and Cities, Westview Press, 1979 等参照。 65)前出の Peirce (1978)、Ford (1979)、Birch (1984)、Weinberg (1979) 等がこのような米国の歴史地区保全の変化を指摘している。

66)このような課題を受けて、全米各地の大学に歴史保全の専門教育プログ ラムが設けられるなど、人材育成が進められた。

67)例えば、Relph, Edward: The Modern Urban Landscape, The John Hopkins University Press, p.223, 1987 は 1970 年代以降の歴史保全に ついて「過去の再生・保存ではなく、あってほしい過去のイメージの選 択であった」と批判している。Barthel (1996) は、都市内コミュニティ 保護の包括は米国の歴史保全の特徴であることを示すとともに、住民意 思を反映することによって生じる学術的観点での問題を指摘している。

68) コミュニティ・商活動の維持・保全上の課題については、City of Seattle, A Decade of Change, 1983 からその概要が把握でき、詳細は 1971 年以 降の地方紙記事から知ることができる。建造物保全上の課題については、 拙著: シアトル市パイク・プレイス・マーケット歴史地区の建造物群保 全における課題, 日本建築学会大会学術講演梗概集 F-2, pp.361- 362, 2009 等参照。 